\section{Sexual Abuse and Exploitation}

\section{of an Adolescent Girl with}

\section{Gender Dysphoria and}

\section{Congenital Adrenal Hyperplasia}

\section{ABSTRACT}

Sexual abuse and exploitation of an adolescent girl with gender dysphoria and congenital adrenal hyperplasia

Gender dysphoria is a psychosexual disorder characterized by powerful cross-gender identification and a continuous dissatisfaction with one's biological gender role. Congenital Adrenal Hyperplasia (CAH) is a sexual developmental disorder resulting from congenital deficiency and functional impairment of enzymes enabling cortisol synthesis. Gender dysphoria may be developed in $5.2 \%$ of CAH patients. In our case, sexual abuse and exploitation of an adolescent girl with gender dysphoria and CAH will be discussed. The 17-year-old girl was admitted to our clinic with complaints of increasing sexual desire for girls, dissatisfaction with being a girl, desire to be male, self-harming, and overstepping personal borders. She sexually touched girls against their will, tried to kiss them, desired to have sex with them, and when they rejected sexual intercourse, she threatened them with a knife when her demands were not met; she attacked the officials at the institution and cut her own arm. In her medical history, a diagnosis of 46XX simple virilizing CAH had been made on the basis of labioscrotal fusion and the presence of a single urogenital opening at 1 month. At the age of 1.5 years, the patient was operated to be raised as a girl and surgical reconstruction was completed. As a result of inadequate parental care, she had been taken into institutional care at the age of 4 . We learned that the patient who was in the institution until the age of 17 was frequently running away from the institution and once had been exposed to sexual abuse. We also learned that she had threatened a girl in her last institution and sexually abused her for 3 months. Gender dysphoria and personality disorder traits were detected in the patient. Genetic and environmental causes may lead to gender dysphoria. As in our case, interest in same-sex partners and forced sexual contact are problems that may occur in gender dysphoria. It should be emphasized that in individuals with genetic or environmental risk factors of gender dysphoria, the risk of developing gender dysphoria and the risk of sexual abuse need to be considered.

Keywords: Congenital adrenal hyperplasia, gender dysphoria, sexual abuse

\section{öz}

Cinsiyet disforisi ve konjenital adrenal hiperplazisi olan bir kız ergenin cinsel istismara uğraması ve cinsel istismarda bulunması

Cinsiyet disforisi, şiddetli olarak kendini karşı cinsten olarak tanımlama ve kendi biyolojik cinsiyetinden sürekli bir memnuniyetsizlikle karakterize psikoseksüel bir hastalıktır. Konjenital Adrenal Hiperplazi (KAH), kortizol sentezini sağlayan enzimlerin konjenital eksikliğinden ve işlevinin bozulmasından kaynaklanan bir cinsel gelişimsel bozukluktur. KAH'ı hastaların \%5.2'sinde cinsiyet disforisi gelişebilir. Bu olguda, cinsiyet disforisi ve KAH'ı olan bir kız ergenin cinsel istismara uğraması ve cinsel istismarda bulunması tartışılacaktır. Onyedi yaşında kız hasta kliniğimize kızlara yönelik cinsel istek artışı, kız olma konusunda memnuniyetsizlik, erkek olma arzusu, kendine zarar verme ve kişisel sınırları aşma şikayetleri ile başvurdu. Kızlarla cinsel ilişkiye girme, öpmeye çalş̧ma, cinsel ilişki isteği geri çevrildiğinde bıçakla tehdit etme, talepleri karşılanmadığında kurum yetkililerine saldırma ve kolunu kesme semptomları mevcuttu. Tibbi öyküsünde, doğumundan sonraki 1. ayında labio-skrotal füzyon ve tek ürogenital açıklık temelinde 46 XX basit virilizan tip KAH tanısı konulmuş, 1.5 yaşında kız olarak yetiştirilmek üzere cerrahi rekonstrüksiyon geçirmiş. Ebeveynlerin yetersiz bakımının bir sonucu olarak, dört yaşındayken kurum bakımına alınmış. Onyedi yaşına kadar kurumda kalan hastanın, kurumdan sık sık kaçtığı ve bir kez cinsel istismara maruz kaldığı öğrenildi. Ayrıca, son kurumunda bir kızı tehdit ettiği ve kıza 3 ay boyunca cinsel istismar uyguladığı öğrenildi. Hastada cinsiyet disforisi ve kişilik bozukluğu özellikleri tespit edildi. KAH'a veya yetersiz bakım ve cinsel sınırların olmamasına bağlı olarak cinsiyet disforisi ortaya çıkabilir. Olgumuzda olduğu gibi, hemcinsine olan ilgi ve zorla cinsel ilişkiye girme cinsiyet disforisinin zorluklarındandır. Cinsiyet disforisinin genetik veya çevresel risk faktörlerine sahip olan bireylerin cinsiyet disforisi geliştirme riskinin göz önüne alınması gerektiği ve bu bireylerin cinsel istismar riskinin artmış olduğu vurgulanmaktadır.

Anahtar kelimeler: Konjenital adrenal hiperplazisi, cinsiyet disforisi, cinsel İstismar
How to cite this article: Ogutlu H, Tiryaki I, Esin IS Dursun OB. Sexual abuse and exploitation of an adolescent girl with gender dysphoria and congenital adrenal hyperplasia. Dusunen Adam The Journal of Psychiatry and Neurological Sciences 2018;31:400-404

https://doi.org/10.5350/DAJPN2018310409

Address reprint requests to / Yazışma adresi Ibrahim Selcuk Esin

Ataturk University, Faculty of Medicine, Department of Child and Adolescent Psychiatry, 25240 Erzurum, Turkey

Phone / Telefon: +90-442-344-6956

E-mail address / Elektronik posta adresi: esinibrahimselcuk@gmail.com

Date of receipt / Geliş tarihi: January 22, 2018 / 22 Ocak 2018

Date of the first revision letter / illk düzeltme öneri tarihi: February 16, 2018 / 16 Şubat 2018

Date of acceptance / Kabul tarihi: April 16, 2018 / 16 Nisan 2018 


\section{INTRODUCTION}

Dsychosexual development is affected by sexual identity, sex role, sex-related behaviors, and sexual adaptation. During sexual identity development, when a person lives or wants to live as a member of the gender opposite to the currently ascribed one and behaves and feels like a person of the opposite sex, gender dysphoria emerges accordingly. Gender dysphoria is defined as the condition of feeling one's emotional and psychological identity (male or female) to be in opposition to one's biological sex. The prevalence of gender dysphoria in the population varies between $0.002-0.014 \%$, being 0.005 $0.014 \%$ for males and $0.002-0.003 \%$ for females (1). Congenital adrenal hyperplasia (CAH), $5 \alpha$-reductase 2 , and $17 ß$-hydroxysteroid dehydrogenase 3 deficiencies are sexual development disorders, and gender dysphoria may be seen in $8.5-20 \%$ of cases suffering from these conditions.

$\mathrm{CAH}$ is an autosomal recessive inherited sexual developmental disorder, resulting from congenital deficiency and functional impairment of enzymes that enable cortisol synthesis from cholesterol. CAH, the most common adrenal disease in children, is seen in approximately 1 in 10,000-20,000 live births (2). Ninety percent of CAH cases suffer from 21-hydroxylase enzyme deficiency. This enzyme is a cytochrome p450 enzyme that converts 17-hydroxyprogesterone to 11-deoxycortisol and progesterone to deoxycorticosterone. CAH due to 21-hydroxylase deficiency is divided into a classical and a non-classical type. The classical type is divided into two groups, the simple virilizing type and the salt-wasting type. In the simple virilizing type, sufficient aldosterone is synthesized to prevent salt loss; however, prenatal virilization occurs. The salt-wasting type is the most severe form of the disease. Since the required aldosterone is not produced, salt loss occurs (3).

$\mathrm{CAH}$ is one of the important genetic causes of gender dysphoria; the frequency of gender dysphoria in $\mathrm{CAH}$ is $5.2 \%$. It is thought that this ratio is much lower in the simple virilizing form of $\mathrm{CAH}(4,5)$. In the development and maintenance of gender dysphoria, environmental as well as genetic factors are of great importance. Family and peer relations, chronic diseases, natural disasters, and any kind of abuse are common environmental factors (6). In particular, it is asserted that there is a strong relationship between gender dysphoria and childhood maltreatment or experience of sexual abuse. Patients with gender dysphoria have a higher risk of exposure to sexual abuse than the general population $(7,8)$. In our case, a female adolescent who had been a victim of sexual abuse and later became a perpetrator of sexual assault was diagnosed with gender dysphoria and $\mathrm{CAH}$, and the consequences of these sexual abuse cases are discussed.

\section{CASE}

A 17-year-old girl was admitted to our clinic unit with complaints of increasing sexual desire for persons of the same sex, dissatisfaction with being a girl, desire to be male, non-compliance with rules, harming herself and others in case her requests were not fulfilled, rapid mood changes, and sense of emptiness. The patient stated that she had sexual intercourse in her dreams. According to information received from the caregiver; she sexually touched girls against their will, tried to kiss and wanted to have sex with them, and when they rejected sexual intercourse, she threatened them with a knife when her demands were not met and attacked the officials at the institution; she cut her own arm, failed at her lessons in class, and frequently played truant.

In her medical history, we learned that she had been diagnosed with 46XX simple virilizing CAH based on labioscrotal fusion and the presence of a single urogenital opening (Prader stage 3 ) at the age of 1 month, and treatment had been started to replace mineralocorticoids with fludrocortisone and hydrocortisone. She had been operated to be raised as a girl at the age of 1.5 years, and surgical reconstruction was completed. After her parents' divorce, she had not received adequate care from them and therefore had been taken into institutional care at the age of 4 .

It was learned that the patient was frequently running away from the institution and had been exposed to sexual abuse once at the age of 15 years. This sexual abuse took place after a concert she had 
attended with her friends while being on the run from the institution. During the concert, she drank alcohol and met an unknown male adult. She was having a good time with this man in the concert. Under the influence of heavy drinking, she went to woodlands outside the concert area with this man. There the person raped her, including vaginal penetration, using force. The patient was shaking, crying, and in pain when the police found her. After the event, she wanted to report the rapist, but because she could not remember his face, the rapist was not apprehended. In the institution, she did not want to talk to anyone and insisted to be alone. Then the patient was transferred to another institution on the assumption that she would benefit from a change of environment. Before this incident, her sexual orientation had been heterosexual. However, we learned that she threatened a girl in her last institution and sexually abused her by digital penetration for 3 months. After the event was discovered, she was moved to a different institution.

In her mental examination, her appearance was like that of an adolescent girl. She dressed and acted like a girl. The patient had a defensive attitude. Her mood was euthymic, and her affection was labile. Emotional lability, aggression, sense of emptiness, psychomotor agitation, and thoughts of dissatisfaction with being female and of transitioning from female to male were present. As a result of our psychiatric evaluation, gender dysphoria and personality disorder traits were detected in the patient.

On the Children's Global Assessment Scale (CGAS), a score of 40 (major impairment) was recorded. It was learned that she was taking $0.5 \mathrm{mg} /$ day dexamethasone for congenital adrenal hyperplasia and risperidone $2 \mathrm{mg}$ /day because of her self-harming behavior and temper outbursts. After our examination, her antipsychotic treatment was adjusted, risperidone was phased out and the treatment was switched to aripiprazole, which was gradually increased to $20 \mathrm{mg} /$ day. In her follow-up sessions, the patient stated that she felt like a man, wanted to have sex with girls, and wanted to be a man and undergo the necessary operation after reaching the age of 18 years, and to live with her mother. Because the patient's self-harming behaviors did not improve and the CGAS score did not change within 8 weeks, aripiprazole was reduced and discontinued. Quetiapine was increased to $500 \mathrm{mg} /$ day step-by-step. In the opinion of the caregiver, the patient's self-harming symptoms significantly decreased. The CGAS score increased to 70 with slight impairment.

In the monthly follow-up examinations, psychosocial interventions for the patient were introduced, starting her on a vocational course, and supportive psychotherapy was applied. Occupation and therapy contributed to clinical improvement.

\section{DISCUSSION}

CAH-related gender dysphoria may occur in persons raised either as male or as female. In adults, gender dysphoria is 2-8 times more common in females than in males, while in adolescents, it is 1.3-3.1 times more common in females than in males $(9,10)$. There are two main reasons for the development of gender dysphoria: genetic and environmental causes. Among the genetic causes are autosomal recessive transition and high association with CAH. Of the patients with 46XX chromosomes who are diagnosed with $\mathrm{CAH}, 94.8 \%$ are satisfied with being raised as a female, while the remaining $5.2 \%$ show gender dysphoria. The main reason for the development of CAH in our case was the inheritance of an autosomal recessive pattern of $\mathrm{CAH}$. The main genetic and environmental risk factors affecting the case are the presence of $\mathrm{CAH}$, the divorce of her parents, the inability of parents to bring up the patient, the necessity of institutional care, and exposure to sexual abuse.

In Table 1, diagnostic criteria of gender dysphoria are listed. In our case, sexual desire for females, dissatisfaction with being female, and the desire to be male were present from among the features of criterion $\mathrm{A}$. The case had impaired functionality, defined as criterion B. Thus, the case was diagnosed with gender dysphoria with congenital adrenal hyperplasia according to DSM-5 (1).

One of the challenges of gender dysphoria is the desire for sex change. The vast majority of women with gender dysphoria want to be male, and this desire for sex change from female to male is 30-400 times higher in females with $\mathrm{CAH}$ than in normal females. Similarly, our patient also has gender dysphoria and 


\section{Table 1: DSM-5 Criteria of Gender Dysphoria in Adolescents and Adults (1)}

A. A marked incongruence between one's experienced/expressed gender and assigned gender, of at least 6 months' duration, as manifested by at least two of the following:

1. A marked incongruence between one's experienced/expressed gender and primary and/or secondary sex characteristics (or in young adolescents, the anticipated secondary sex characteristics).

2. A strong desire to be rid of one's primary and/or secondary sex characteristics because of a marked incongruence with one's experienced/expressed gender (or in young adolescents, a desire to prevent the development of the anticipated secondary sex characteristics).

3. A strong desire for the primary and/or secondary sex characteristics of the other gender.

4. A strong desire to be of the other gender (or some alternative gender different from one's assigned gender).

5. A strong desire to be treated as the other gender (or some alternative gender different from one's assigned gender).

6. A strong conviction that one has the typical feelings and reactions of the other gender (or some alternative gender different from one's assigned gender).

B. The condition is associated with clinically significant distress or impairment in social, occupational or other important areas of functioning.

Specify if: With a disorder of sex development (e.g., a congenital adrenogenital disorder such as 255.2 [E25.0] congenital adrenal hyperplasia or 259.50 [E34.50] androgen insensitivity syndrome).

$\mathrm{CAH}$ and wants to change her sex in her future life. However, the proportion of women who have experienced gender change is the same as in the normal population. CAH females are very unlikely to be able to change their gender, even if they want to transition due to social stigmatization (5).

In the treatment, the patient should be supported with psychosocial interventions while being in institutional care. Occupation like school, sports, or vocational courses must be maintained. Thus, patients increase their functionality in the community (11). Psychological interventions should be focused on bolstering their coping and adaptation skills and functionality. There is no such goal as eliminating gender dysphoria. In the follow-up sessions, it should be aimed to achieve a state of well-being. While working with family members, psychoeducation should be given to the family and they should be encouraged to support the patient. Cognitive behavioral therapy (CBT) can be applied for gender dysphoria. CBT focuses on body image, helping to change body perception and reduce self-harming behavior. It is also used in the treatment of comorbid diseases of gender dysphoria (12). Temper outbursts and self-harming behavior can be reduced by psychological and pharmacological interventions. Antipsychotics are frequently used in the pharmacological treatment of adolescent aggression. All antipsychotics, especially risperidone and aripiprazole, which are approved by the US Food and Drug Administration (FDA) for treating irritability in autism patients, may be used in the treatment of aggression. In the pharmacological treatment of our patient, risperidone and aripiprazole were tried. Since the patient did not benefit from these drugs, treatment was switched to quetiapine, another antipsychotic medication $(13,14)$.

This case report showed for the first time sexual abuse and exploitation suffered and perpetrated by an adolescent girl with gender dysphoria and congenital adrenal hyperplasia. In order to prevent sexual abuse, children should be given adequate care by their parents and receive sexual education and sexual abuse prevention training by professionals. In particular, patients with $\mathrm{CAH}$ are less likely to experience sexual development problems when they receive adequate care and support from their families $(6,15)$. In addition, sexual education and sexual abuse prevention training are effective to prevent sexual abuse, especially for high school children (16). A psychiatrist and a psychologist should follow up children with a high risk of sexual abuse, such as those with gender dysphoria or CAH. If problems are encountered during follow-up sessions, interventions should be made immediately before complications occur. We suggest that taking the necessary precautions for our patient, who displays prominent risk factors for gender disorder, can be effective in preventing sexual assault. Consequently, it is important to note that in individuals with genetic or environmental risk factors of gender dysphoria, the risk of developing gender dysphoria should be considered. In order to prevent abuse, sex education and psychiatric follow up should be provided to children with a high risk of sexual abuse. 


\begin{tabular}{|l|l|l|}
\hline \multicolumn{1}{|l|}{ Contribution Categories } & Author Initials \\
\hline \multirow{3}{*}{ Category 1} & Concept/Design & I.S.E., H.O. \\
\cline { 2 - 3 } & Data acquisition & I.T., H.O. \\
\cline { 2 - 3 } & Data analysis/Interpretation & I.S.E., O.B.D. \\
\hline \multirow{3}{*}{ Category 2} & Drafting manuscript & H.O., I.T. \\
\cline { 2 - 3 } & Critical revision of manuscript & H.O., I.S.E., O.B.D. \\
\hline Category 3 & Final approval and accountability & H.O., I.T. \\
\hline \multirow{3}{*}{ Other } & Technical or material support & I.S.E. \\
\cline { 2 - 3 } & Supervision & H.O., O.B.D. \\
\cline { 2 - 3 } & Securing funding (if applicable) & N/A \\
\hline
\end{tabular}

\section{REFERENCES}

1. American Psychiatric Association. Diagnostic and Statistical Manual of Mental Disorders. Fifth ed., Washington D.C: American Psychiatric Association, 2013.

2. Khalid JM, Oerton JM, Dezateux C, Hindmarsh PC, Kelnar CJ, Knowles RL. Incidence and clinical features of congenital adrenal hyperplasia in Great Britain. Arch Dis Child 2012; 97:101-106. [CrossRef]

3. White PC. Congenital adrenal hyperplasias. Best Pract Res Clin Endocrinol Metab 2001; 15:17-41. [CrossRef]

4. Furtado PS, Moraes F, Lago R, Barros LO, Toralles MB, Barroso U Jr. Gender dysphoria associated with disorders of sex development. Nat Rev Urol 2012; 9:620-627. [CrossRef]

5. Dessens AB, Slijper FM, Drop SL. Gender dysphoria and gender change in chromosomal females with congenital adrenal hyperplasia. Arch Sex Behav 2005; 34:389-397. [CrossRef]

6. Zucker KJ, Bradley SJ. Gender identity and psychosexual disorders. Focus. 2005; 3:598-617. [CrossRef]

7. American College of Pediatricians. Gender Dysphoria in Children. https://www.acpeds.org/the-college-speaks/position-statements/ gender-dysphoria-in-children. Accessed November 26, 2018.

8. Roberts AL, Glymour MM, Koenen KC. Considering alternative explanations for the associations among childhood adversity, childhood abuse, and adult sexual orientation: reply to Bailey and Bailey (2013) and Rind (2013). Arch Sex Behav 2014; 43:191196. [CrossRef]

9. Blanchard R, Clemmensen LH, Steiner BW. Heterosexual and homosexual gender dysphoria. Arch Sex Behav 1987; 16:139152. [CrossRef]
Informed Consent: Written consent was obtained from the participants.

Peer-review: Externally peer-reviewed.

Conflict of Interest: Authors declared no conflict of interest.

Financial Disclosure: Authors declared no financial support.

10. Aitken M, Steensma TD, Blanchard R, VanderLaan DP, Wood H, Fuentes A, Spegg C, Wasserman L, Ames M, Fitzsimmons CL, Leef JH, Lishak V, Reim E, Takagi A, Vinik J, Wreford J, CohenKettenis PT, de Vries AL, Kreukels BP, Zucker KJ. Evidence for an altered sex ratio in clinic-referred adolescents with gender dysphoria. J Sex Med 2015; 12:756-763. [CrossRef]

11. Bockting W, Coleman E. A comprehensive approach to the treatment of gender dysphoria. J Psychol Human Sex 1993; 5:131-155. [CrossRef]

12. Muth JL, Cash TF. Body-image attitudes: what difference does gender make? J Appl Soc Psychol 1997; 27:1438-1452. [CrossRef]

13. Harrison JN, Cluxton-Keller F, Gross D. Antipsychotic medication prescribing trends in children and adolescents. J Pediatr Health Care 2012; 26:139-145. [CrossRef]

14. Owen R, Sikich L, Marcus RN, Corey-Lisle P, Manos G, McQuade RD, Carson WH, Findling RL. Aripiprazole in the treatment of irritability in children and adolescents with autistic disorder. Pediatrics 2009; 124:1533-1540. [CrossRef]

15. Zucker KJ. Cross-gender-identified children: In Steiner BW (editor). Gender Dysphoria. Springer, 1985, 75-174. [CrossRef]

16. Ogunfowokan AA, Fajemilehin RB. Impact of a school-based sexual abuse prevention education program on the knowledge and attitude of high school girls. J Sch Nurs 2012; 28:459-468.

\section{[CrossRef]}

